\title{
THE REACTION OF CAPITAL MARKETS IN INDONESIA, SINGAPORE, MALAYSIA, AND THAILAND TOWARDS THE ANNOUNCEMENT OF LOCKDOWN POLICY DURING THE BEGINNING OF THE COVID-19
}

\author{
Lailatul Fauziah, Lintang Venusita \\ Universitas Negeri Surabaya
}

\begin{abstract}
This study aims to examine the stock market's reaction to the announcement of the implementation of the Covid-19 lockdown policy, examining the differences in abnormal return, and the total volume activity in company shares in Indonesia, Singapore, and Malaysia in responding before and after the announcement of the lockdown policy in the countries. This study uses the even study method and is based on secondary data from news portals and websites. The population and sample used in this study are companies listed in the index with the largest capitalization in each country, including LQ45 in Indonesia, STI in Singapore, FBM KCLI in Malaysia, and SET50 in Thailand. The sample collection technique is based on purposive sampling technique. The research variables are the Covid-19 lockdown policy announcement, abnormal return, trading volume activity (TVA) in the form of trading volume in the companies as the sample group. The results show that the announcement of Covid-19 lockdown policy did not significantly influence the reaction of the capital market but was still used as a basis to make investments decision. The announcement of the Covid-19 lockdown, both before and after the announcement, did not have a significant effect on abnormal returns and trading volume activity in Indonesia, Singapore, Malaysia, and Thailand capital markets.
\end{abstract}

Keywords: Covid-19 lockdown policy, market reaction, abnormal return, total volume activity (TVA)

\section{INTRODUCTION}

Covid-19 pandemic is a condition stated by the World Health Organization (WHO) as the coronavirus causes a large number of confirmed cases approaching

\footnotetext{
*Corresponding Author. e-mail: lailatul.17080694068@mhs.unesa.ac.id
} 
200,000, with deaths exceeding 8.000 in more than 160 countries (Spinelli \& Pellino, 2020). In addition, Indonesian stock exchange explained that the world's stock exchanges experienced a simultaneous decline in stock prices during the pandemic. The decline in share prices around the world shows that Covid-19 pandemic is indirectly affecting the capital markets. The sensitivity occurs because the capital market responds to the published information as bad news for the capital market. Information published during a pandemic will affect the capital market conditions, such as information about the increase number of cases in the news which can lead to a decrease in share prices (Haryanto, 2020).

Asian capital market reactions show a negative result because there is a difference in the abnormal return value before and after WHO announced that the corona virus as a Covid-19 pandemic or a global pandemic. This is also shown by how several Asian countries were experiencing a decline in share prices as soon as the announcement is published, including Indonesia, Singapore, Malaysia, and Thailand. Singapore Straits Time Index (STI) shows a negative response of $3,77 \%$; a decline to $2.678,640$ point from $2.783,72$ point. Indonesian Indeks Harga Saham Gabungan (IHSG), IDX Composite, also show a negative response, shown by the decline of IHSG value to the lowest point of $4,36 \%$ to $4.929,56$, while one day before the announcement were made, IHSG was valued at 5.154,105 (Saragih, 2020). Kuala Lumpur Composite Index (KLCI) also responded negatively shown by the drop of the stock index of 1,69\% or a decrease of 24.40 points of $1,419,43$ points from $1,443.83$ points. Like the three countries, Thailand's capital market responded negatively by a dropping of share price by 111,52 point to $1.003,39$ point on the day of the announcement.

A number of policies implemented by the governments that are affected by the Covid-19 are the lockdown (national lockdown), travel restrictions, and stimulus packages (packages to offer support to workers and businesses who have lost their jobs and income) (Narayan et al., 2020). The policies will be an important event for the capital market when it affects the sensitivity of the capital market. These policies have been implemented by some countries, including Indonesia, Singapore, Malaysia, and Thailand. The policies issued by the government are thought to be able to influence the countries' stock market (Shen et al., 2017).

The stock price index movements in Indonesia, Singapore, and Thailand tend to be able to survive in the period of March 2020, which is when the 
lockdown was announced. However, Malaysia shows a slight decline in the span of the month. This shows that the policies made by the government affect companies' performances, which will also affect investor's behaviours in the capital market. Investors' behaviours can lead to fluctuations in stock prices in the capital market. Some studies show the influence of government policies on capital markets in several countries. Anh (2020) study show that lockdown policy in Vietnam brought a positive and significant impact on the performance of capital market in Vietnam, as seen from the market-to-book ratio, return on equity and industry factor. In line with this finding, Huo \& Qiu (2020) study shows that that lockdown policy in China has a positive reaction, shown by the positive changes in the value of abnormal return or ta positive return reaction around the event window. On the other hand, the existence of regulatory restriction policies in the United States (US) can endangered the quality of the financial market (Baig et al., 2020). This shows that government policies are seen a positive or negative effect, depending on the response of the capital market in assessing information from these events.

According to the discussion above, the announcement of the lockdown policy is one of the economic events that can affect the capital market conditions. All policies disclosed by the government can affect the capital market. Ferguson (2016) stated that certain policies can affect strong capital markets, where the event shows a direct relationship between the investor's assessment of the possibility of policy changes and the emergence of news about the events, such as politics. In this case, investors can directly or indirectly reach, which is reflected from their expectations on the events based on their activities carried out in the capital market. This study is conducted to examine the capital market reactions towards the announcement of the Covid-19 pandemic lockdown policy in Southeast Asia. The capital market included in this study are from Indonesia, Singapore, Malaysia, and Thailand. These countries are chosen because the four countries are members of the ACE (ASEAN Economic Community) agreement. Thus, this study is titled as "The reaction of Capital Markets in Indonesia, Singapore, Malaysia, and Thailand towards the Announcement of Lockdown Policy during the Beginning of the Covid-19 Pandemic.”

This study observes the impact of announcement of the Covid-19 pandemic lockdown policy towards the capital market in Indonesia, Singapore, Malaysia, and Thailand, thus the research hypotheses are as follow: 
H1a: There is a capital market reaction around the dates of the initial announcement of Covid-19 lockdown policy in Indonesian capital market on LQ45 Index.

$\mathrm{H} 1 \mathrm{~b}$ : There is a capital market reaction around the dates of the initial announcement of Covid-19 lockdown policy in Singapore capital market on STI Index.

H1c: There is a capital market reaction around the dates of the initial announcement of Covid-19 lockdown policy in Malaysian capital market on FBM Kuala Lumpur Composite Index.

H1d: There is a capital market reaction around the dates of the initial announcement of Covid-19 lockdown policy in Thailand capital market on SET50.

$\mathrm{H} 2 \mathrm{a}$ : There is a significant difference in the average of abnormal return before and after the announcement of Covid-19 lockdown policy in Indonesian capital market on LQ45 Index.

$\mathrm{H} 2 \mathrm{~b}$ : There is a significant difference in the average of abnormal return before and after the announcement of Covid-19 lockdown policy in Singapore capital market on STI Index.

$\mathrm{H} 2 \mathrm{c}$ : There is a significant difference in the average of abnormal return before and after the announcement of Covid-19 lockdown policy in Malaysian capital market on FBM Kuala Lumpur Composite Index.

$\mathrm{H} 2 \mathrm{~d}$ : There is a significant difference in the average of abnormal return before and after the announcement of Covid-19 lockdown policy in Thailand capital market on SET50.

$\mathrm{H} 3 \mathrm{a}$ : There is a significant difference in the average of Trading Volume Activity before and after the announcement of Covid-19 lockdown policy in Indonesian capital market on LQ45 Index.

$\mathrm{H} 3 \mathrm{~b}$ : There is a significant difference in the average of Trading Volume Activity before and after the announcement of Covid-19 lockdown policy in Singapore capital market on STI Index.

$\mathrm{H} 3 \mathrm{c}$ : There is a significant difference in the average of Trading Volume Activity before and after the announcement of Covid-19 lockdown policy in in Malaysian capital market on FBM Kuala Lumpur Composite Index. 
H3d: There is a significant difference in the average of Trading Volume Activity before and after the announcement of Covid-19 lockdown policy in in Thailand capital market on SET50.

\section{METHOD}

The type of research used in this study is event study. Hartono (2017) explains that event study research method can be used to assess the content of information in an announcement. In this study, the event used to be studied is when the government announce the Covid-19 pandemic lockdown policy to the public in each country of Indonesia, Singapore, Malaysia, and Thailand. This study uses a quantitative research method because the data used is in the form of numbers and is used as an analysing tool to determine the relationship between variables. This study uses data in the form of secondary data. The researcher of this study obtained the data indirectly though intermediate media.

\section{Population and Sample}

Population and sample used in this study is companies listed on the index with the largest capitalization in each country including LQ45 in Indonesia, STI in Singapore, FBM KCLI in Malaysia and SET50 in Thailand. The sample collection technique of this study is based on purposive sampling. Taking sample group with purposive sampling technique means that the sample is selected from a predetermined population from certain criteria according to the wishes of the researcher (Sugiyono, 2013). The total sample from the population used in each country is shown in Table 1 as follow:

Table 1 Research Population and Sample

\begin{tabular}{ccc}
\hline Country & Population & Sample \\
\hline Indonesia & 45 & 43 \\
Singapore & 30 & 25 \\
Malaysia & 30 & 16 \\
Thailand & 49 & 40 \\
\hline
\end{tabular}




\section{Research Variables and Operational Definitions}

The following section will explain the operational definition of each variable that will be used in this study, inducing:

\section{Event}

The events used in this study are the period where the government first announce the Covid-19 lockdown in each country. This study uses the reference date of the events to determine the study period. The event period or event window is 15 days, which includes 7 days before the event, 1 day of the event, and 7 days after the event. The events and the event windows are presented in Table 2 below.

Table 2 Announcement Dates of the Early Lockdown Covid-19 Policy

\begin{tabular}{lc}
\hline \multicolumn{1}{c}{ Event } & Event date \\
\hline Lockdown Announcement in Indonesia & 31 March 2020 \\
Lockdown Announcement in Singapore & 24 March 2020 \\
Lockdown Announcement in Malaysia & 16 March 2020 \\
Lockdown Announcement in Thailand & 24 March 2020 \\
\hline
\end{tabular}

\section{Abnormal Return}

$$
\mathrm{RTN}_{i, t}=\mathrm{R}_{i . t}-\mathrm{E}\left(\mathrm{R}_{i . t}\right)
$$

Abnormal return can be defined as the differences between the actual return received and the return that was expected or calculated prior. Abnormal return can be calculated using the following formula:

\section{Description:}

$\mathrm{RTN}_{\mathrm{i}, \mathrm{t}}=$ Abnormal return from of the $\mathrm{i}^{\text {th }}$ security in the $\mathrm{t}$ event period

$\mathrm{R}_{\mathrm{i}, \mathrm{t}}=$ The actual return from the $\mathrm{i}^{\text {th }}$ security in the $\mathrm{t}$ event period $\mathrm{E}\left(\mathrm{R}_{\mathrm{i}, \mathrm{t})}=\right.$ The expected return from the $\mathrm{i}^{\text {th }}$ security in the $\mathrm{t}$ event period

Normally, abnormal return does not fully use the abnormal return value from a company tested, but by testing the average abnormal return value to all 
companies with a cross-sectional to test daily in the specified event period (Hartono, 2017). Thus, the formula used to know the average abnormal return is as follow:

$$
\operatorname{RRTN}_{\mathrm{t}}=\frac{\sum_{\mathrm{i}=1}^{\mathrm{N}} \operatorname{RTN}_{\mathrm{i}}, \mathrm{E}}{\mathrm{N}}
$$

Description:

RRTN $_{t}=$ The average of abnormal return from the $i^{\text {th }}$ security in the t-event period

$\mathrm{N} \quad=$ Total of securities

$\mathrm{RTN}_{\mathrm{i}, \mathrm{t}}=$ Abnormal return from of the $\mathrm{i}^{\text {th }}$ security in the $\mathrm{t}$-event period

The actual return value with the expected return is obtained through the formula below, along with an explanation of each value.

\section{a. Return}

Return is the outcome of return on investment made. In this study, return means the realization or return that is indeed received by the investors. The return is obtained from the stock price index of companies listed on the stock market with the largest market capitalization of LQ45 in Indonesia, STI in Singapore, and FBM KCLI in Malaysia. According to (Hartono, 2017), Realization return formula is:

$$
\mathrm{R}_{i . t}=\frac{P_{\mathrm{i} \cdot t}-P_{\mathrm{i} \cdot t-1}}{P_{\mathrm{i} \cdot t-1}}
$$

Description:

$\mathrm{R}_{i . t}=$ The actual return from the $\mathrm{i}^{\text {th }}$ security in the $\mathrm{t}$-event period

$\mathrm{P}_{i, t}=$ The security price in the $\mathrm{t}$ event period

$\mathrm{P}_{\mathrm{i}, \mathrm{t}-1}=$ The security price in the $\mathrm{t}-1$ event period

\section{b. Expected return}

Expected return is the return that has not been obtained by the investors but is the expected return that will be received in the future. Expected return can be calculated using a market-adjusted model, with the formula of (Hartono, 2017): 


$$
\mathrm{E}(\mathrm{Ri}, \mathrm{t})=\mathrm{Rm}, \mathrm{t}
$$

Description:

$\mathrm{E}(\mathrm{Ri}, \mathrm{t})=$ The expected return value

$\mathrm{Rm}, \mathrm{t}=$ market return in $\mathrm{t}$ period

\section{Trading Volume Activity (TVA)}

Trading volume activity (TVA) can be interpreted as a parameter about the activity of changes in the volume of trading of shares on the stock exchange in each company. (Fatmawati \& Marwan), in (Wardhani, 2012). Trading volume activity data used in this study were trading volume at companies listed on of LQ45 in Indonesia, STI in Singapore, FBM KCLI in Malaysia, and SET50 in Thailand. The data were obtained from website yahoo.finance.com and Investing.com within the period of 7 days before the event, the event day, and 7 days after the event.

\section{Data Collection Techniques and Data Analysis}

The data collection technique used in this study is based on the documentation technique. Documentation technique is a technique of collecting data by finding information related to the research variables and other information from intermediary media, such as news, books, transcripts, online websites, minutes, and so on. In this study, the data were obtained via news portals, website idx.co.id, website sgx.com, bursamalaysia.com, set.or.th, website Yahoofinance, and Investing.com. The research method used in this study is the event study method. This method is chosen in this study to see the reaction of stock price movements within the observation period.

\section{Data Normality Testing}

The normality test is conducted to see the data distribution and to determine the statistical tests that will be used in the study. The test determines whether the study needs to use parametric statistical tools or non-parametric tests. The test was conducted via SPSS media with the One-Sample Kolmogorov Test. In this 
procedure, the data is said to be normally distributed when the Asym sig (2tailed) from the test is greater than the degree of confidence. If the value of significant is $>0,05$, then the data is normally distributed. On the other hand, if the value of significant is $<0,05$, thus the data is not normally distributed. If the test results show that the data is normally distributed, thus parametric statistics can be used with the t-test for paired data (paired sample t-test). However, if the data is not normally distributed, then the non-parametric statistic will be used via the Wilcoxon Signed Rank Test.

\section{Hypothesis 1 Test}

The first hypothesis test is conducted to see the significant value of abnormal return during the observation period. This testing is conducted to see whether the event being tested is good news or bad news for the investors. The assessment of the significance of abnormal return is carried out with the One sample t-test to see whether there is a significant abnormal return in that period. The significant value is obtained by comparing the $t$ count value with the $t$ table from each capital market test. If the value of $t$ is greater than the $t$ table, thus $\mathrm{H} 0$ is rejected and vice versa. The following are the steps to test hypothesis 1 :

a. Formulate research hypothesis.

$\mathrm{H} 0$ : There is no significant capital market reaction to the initial announcement of Covid-19 lockdown policy in Indonesia, Singapore, Malaysia, and Thailand.

H1: There is significant capital market reaction to the initial announcement of Covid-19 lockdown policy in Indonesia, Singapore, Malaysia, and Thailand.

b. Determine the t-table value of each county to determine the results of the hypothesis testing.

c. Conduct Hypothesis 1 testing via one sample t-test on each country studied. After the result of data testing are obtained, the process of comparing the calculated $t$-value obtained from the predetermined $t$-table is conducted. If the calculated $t$ value is greater than the $t$-table, then $\mathrm{H}-0$ is rejected and vice versa. 


\section{Hypothesis 2 Test}

In this study, hypothesis 2 explains that there is a difference in the average value of abnormal return before and after the announcement of the implementation of the initial Covid-19 lockdown policy. Hypothesis 1 test in this study is conducted by comparing the average value of abnormal return before and after the announcement of Covid-19 lockdown policy. The average event tested in this study it an average of 7 days before the even and 7 days after the announcement of Covid-19 lockdown policy. A statistical test is conducted to see the result of the normality test that has been previously conducted. If the data is normally distributed, thus the statistic test will be based on paired-sample t-test. This test is used to see whether there are differences in the average values between two group that are related (Sugiyono, 2013). The decision making is made based on the value of Asym-sig found in the statistic test. If the significant value is greater than 0,05 , thus $\mathrm{H} 0$ is accepted and vice versa. Below are the steps to conduct hypothesis 2, including:

a. Formulate research hypothesis.

H0: There is no significant different in the average of abnormal return ASEAN (Indonesia, Singapore, Malaysia, and Thailand)

H1: There is a significant different in the average of abnormal return ASEAN (Indonesia, Singapore, Malaysia, and Thailand)

b. Conduct hypothesis testing using the Paired-sample t-test to see if the results of the data normality test show that the data is normally distributed. If the results show that the data is not normally distributed, then the next test will be conducted with a non-parametric test via Wilcoxon Signed Rank Test.

\section{Hypothesis 2 Test}

In this study, hypothesis 2 explains that there is no difference in values before and after the initial announcement of Covid-19 lockdown policy. Hypothesis 2 testing is conducted by comparing the average values of trading volume activity of 7 days before the event with the average of 7 days after the event. The stages taken to conduct hypothesis 2 testing includes: 
a. Formulate research hypothesis.

H0: There is no significant difference in trading volume activity before and after the initial announcement of Covid-19 lockdown policy in ASEAN (Indonesia, Singapore, Malaysia, and Thailand).

H1: There is no significant difference in trading volume activity before and after the initial announcement of Covid-19 lockdown policy in ASEAN (Indonesia, Singapore, Malaysia, and Thailand).

b. Calculate the average value of Trading volume activity.

c. Conduct hypothesis testing using the Paired-sample t-test to see if the results of the data normality test show that the data is normally distributed. If the results show that the data is not normally distributed, then the next test will be conducted with a non-parametric test via Wilcoxon Signed Rank Test. Decision making from the results of the test is conducted by looking at the Asym-sig value in the statistical test. If the significance value is more than 0.05 , thus $\mathrm{H} 0$ is accepted. On the other hand, if the value of the significance is less than 0,05 , thus $\mathrm{H} 1$ is accepted.

\section{RESULTS}

\section{Results of the Observation}

\section{Normality Test}

In this study, the first test conducted is the data normality test. This test is conducted to find out whether the data used in this study is normally distributed. Thus, the next tool of analysis to test the hypothesis used in this study can be determined. The normality test will be done with the one-sample KolmogorovSmirnov. This result of this test will show if the data is normally distributed when the value of Asym-sig (2-tailed) is bigger than 0,05 and on the other hand, if the value of Asym-sig (2-tailed) is smaller than 0,05 then the data is not normally distributed.

According to the normality test shown in Table 3, the Average Abnormal Return (AAR) and Average Trading Volume Activity (ATVA) data with one sample Kolmogorov-Smirnov shows that the Indonesian and Thailand AAR before and after the event is normally distributed because the value of Asym-sig (2-tailed) is 
Table 3 Results of Data Normality Test from One-Sample Kolmogorov-Smirnov Test

\begin{tabular}{llllll}
\hline & \multicolumn{2}{c}{$\begin{array}{c}\text { Asym. Sig } \\
\text { (2-tailed) } \\
\text { AAR }\end{array}$} & \multicolumn{2}{c}{$\begin{array}{c}\text { Asym. Sig } \\
\text { (2-tailed) }\end{array}$} & Test Distribution \\
& ATVA & \\
Indonesia & .200 & .200 & .200 & .015 & Normal-Not \\
ningapura & .200 & .200 & .200 & .200 & Normal-Normal \\
Malaysia & .200 & .200 & .098 & .200 & Normal-Normal \\
Singapura & .200 & .200 & .153 & .000 & Normal - Not \\
\hline
\end{tabular}

greater than 0,05. However, Indonesian and Thailand ATVA is not normally distributed because the value of Asym-sig (2-tailed) is less than 0,05. While the AAR and ATVA variable for Singapore and Malaysia are normally distributed because the value of Asym-sig (2-tailed) is greater than 0,05. So based on the result, the analysing tools for hypothesis 1 and hypothesis 2 can be determined.

\section{Hypothesis 1 Test}

In the second hypothesis testing, it is conducted to see the reaction of the capital market around the date of the initial announcement of the Covid-19

Table 4 Results of One Sample t-test Average Abnormal Return of Indonesia

\begin{tabular}{lrrcl}
\hline \multicolumn{1}{c}{ AAR } & t count & Df & Sig. (2-tailed) & \multicolumn{1}{c}{ Description } \\
\hline TMIN7 & -1.590 & 42 & .119 & Not Significant \\
TMIN6 & .375 & 42 & .710 & Not Significant \\
TMIN5 & -4.080 & 42 & .000 & Significant \\
TMIN4 & -.285 & 42 & .777 & Not Significant \\
TMIN3 & 1.893 & 42 & .065 & Significant \\
TMIN2 & 3.164 & 42 & .003 & Significant \\
TMIN1 & -6.342 & 42 & .000 & Significant \\
DDAY & 1.979 & 42 & .054 & Significant \\
TPLUS1 & -1.813 & 42 & .077 & Significant \\
TPLUS2 & 2.006 & 42 & .051 & Significant \\
TPLUS3 & 1.402 & 42 & .168 & Not Significant \\
TPLUS4 & 4.296 & 42 & .000 & Significant \\
TPLUS5 & 2.004 & 42 & .052 & Significant \\
TPLUS6 & -7.021 & 42 & .000 & Significant \\
TPLUS7 & .524 & 42 & .603 & Not Significant \\
\hline
\end{tabular}


pandemic lockdown policy by the government from the value of the daily Average abnormal return within the observation period. The following is the results of the test on the reaction of the capital market around the date of the initial announcement of the Covid-19 pandemic lockdown policy in Indonesia, Singapore, Malaysia, and Thailand with the one sample t-test.

Table 4 shows the result of the significant reaction during the observation period. The significant value in the study is $5 \%$ with a value of $t$ table amounting 1.682. The capital market reaction occurred significantly over several days of the observation period because the $\mathrm{t}$-count value is bigger than the $\mathrm{t}$-table. Positive significant reactions occurred at $\mathrm{t}-3$ (1.893), $\mathrm{t}-2$ (3.164), $\mathrm{t} 0$ (1.979), $\mathrm{t}+2$ (4.296) and $t+5(2.004)$ because the $t$-count during the period is higher than the $t$ table (1.682). The positive significant value shows that investors consider the incoming information as good news for the stock market. Meanwhile, significant negative reactions occurred at $t-5(-4.080), 1(-6.342)$, and $t+1(-1.813)$ shows that the investors consider the incoming information as bad news for the stock market.

Table 5 Results of One Sample t-test Average Abnormal Return of Singapore

\begin{tabular}{|c|c|c|c|c|}
\hline AAR & $t$ count & Df & Sig. (2-tailed) & Description \\
\hline TMIN7 & -0.622 & 24 & .540 & Not Significant \\
\hline TMIN6 & 1.499 & 24 & .147 & Not Significant \\
\hline TMIN5 & -1.735 & 24 & .096 & Significant \\
\hline TMIN4 & 0.033 & 24 & .974 & Not Significant \\
\hline TMIN3 & -0.532 & 24 & .599 & Not Significant \\
\hline TMIN2 & 0.409 & 24 & .686 & Not Significant \\
\hline TMIN1 & 0.62 & 24 & .541 & Not Significant \\
\hline DDAY & -1.575 & 24 & .128 & Not Significant \\
\hline TPLUS1 & -0.502 & 24 & .620 & Not Significant \\
\hline TPLUS2 & 1.872 & 24 & .073 & Significant \\
\hline TPLUS3 & 0.059 & 24 & .953 & Not Significant \\
\hline TPLUS4 & 1.138 & 24 & .266 & Not Significant \\
\hline TPLUS5 & 1.205 & 24 & .240 & Not Significant \\
\hline TPLUS6 & 1.168 & 24 & .254 & Not Significant \\
\hline TPLUS7 & -1.147 & 24 & .263 & Not Significant \\
\hline
\end{tabular}

The reaction of capital market in Singapore on the initial announcement of the Covid-19 pandemic lockdown policy in its country shows a significant reaction on certain days. A significant negative reaction happened at $\mathrm{t}-5(-1.735)$ 
and positive at $t+2(1.872)$ because the $t$-count value is greater than the $t$ table (1.712). However, on the day when the announcement of the policy was made by the government, the market did not show a reaction because the $t$-count at t0(-1.575) is smaller than the $t$ table (1.712). The absence of this reaction is possible because there is initial information that had been spread beforehand.

Table 6 Results of One Sample t-test Average Abnormal Return of Malaysia

\begin{tabular}{lrrcc}
\hline AAR & t count & Df & Sig. (2-tailed) & Description \\
\hline TMIN7 & -1.718 & 16 & .105 & Not Significant \\
TMIN6 & 0.839 & 16 & .414 & Not Significant \\
TMIN5 & 0.727 & 16 & .478 & Not Significant \\
TMIN4 & -0.725 & 16 & .479 & Not Significant \\
TMIN3 & 1.116 & 16 & .281 & Not Significant \\
TMIN2 & 1.045 & 16 & .311 & Not Significant \\
TMIN1 & 0.214 & 16 & .833 & Not Significant \\
DDAY & 0.716 & 16 & .484 & Not Significant \\
TPLUS1 & 1.186 & 16 & .253 & Not Significant \\
TPLUS2 & 1.018 & 16 & .324 & Not Significant \\
TPLUS3 & 0.335 & 16 & .742 & Not Significant \\
TPLUS4 & -0.715 & 16 & .485 & Not Significant \\
TPLUS5 & -0.117 & 16 & .909 & Not Significant \\
TPLUS6 & -1.411 & 16 & .178 & Not Significant \\
TPLUS7 & 0.33 & 16 & .745 & Not Significant \\
\hline
\end{tabular}

Table 6 shows the result of the significant reaction in Malaysia during the observation period, looking at the average abnormal return value from the initial announcement of the Covid-19 pandemic lockdown policy in the country. The result shows that within the observation period, Malaysian capital market shows that there is no significant reaction during the observation period because the value of $t$-count is smaller than the $t$ table (1.746).

Table 7 shows the result of significant testing on the capital markets via the value of abnormal return regarding the announcement of lockdown policy during the start of Covid-19 in the country. The tests show that during the observation period, there are significant reactions on several days within the period. Positive significant reactions in the market happened during the period of 7 (3.248), t- 
Lailatul Fauziah, Lintang Venusita / The Reaction of Capital Markets in Indonesia, Singapore, Malaysia, and Thailand towards the Announcement of Lockdown Policy During the Beginning of the Covid-19

Table 7 Results of One Sample t-test Average Abnormal Return of Thailand

\begin{tabular}{ccccl}
\hline AAR & t count & Df & Sig. (2-tailed) & Description \\
\hline TMIN7 & 3.248 & 39 & .002 & Significant \\
TMIN6 & -1.756 & 39 & .087 & Significant \\
TMIN5 & -.642 & 39 & .525 & Not Significant \\
TMIN4 & .144 & 39 & .887 & Not Significant \\
TMIN3 & 1.877 & 39 & .068 & Significant \\
TMIN2 & 1.468 & 39 & .150 & Not Significant \\
TMIN1 & -3.444 & 39 & .001 & Significant \\
DDAY & -1.411 & 39 & .166 & Not Significant \\
TPLUS1 & 1.100 & 39 & .278 & Not Significant \\
TPLUS2 & 1.254 & 39 & .217 & Not Significant \\
TPLUS3 & 2.594 & 39 & .013 & Significant \\
TPLUS4 & -1.457 & 39 & .153 & Not Significant \\
TPLUS5 & 1.040 & 39 & .305 & Not Significant \\
TPLUS6 & -1.318 & 39 & .195 & Not Significant \\
TPLUS7 & .495 & 39 & .623 & Not Significant \\
\hline
\end{tabular}

$3(1.877)$, and $t+3(2.594)$. While the negative significant reactions happened during the period of $t-7$ (3.248), $t-3(1.877)$, and $t+3(2.594)$. The presence of positive or negative reactions are indicated by the value of $t$-count is greater than the $t$ table $(1,684)$ during the period. While significant reaction in the capital market does not occur during the day of when the policy is announced by the government because the value of $t$ table $(-1.411)$ is smaller than the $t$-count $(1,684)$. This is possible as the investors may have received information prior the announcement of the policy.

\section{Hypothesis 2 Test}

On the third test, hypothesis 2 testing is conducted to see whether there is a difference of reaction before and after the announcement of the Covid-19 pandemic lockdown policy from the average value of abnormal return in each country. Based on the normality test, Hypothesis 1 testing is conducted using paired sample t-test because all AAR data in all counties are normally distributed. 
Table 8 Results of Paired Sample t-test Average Abnormal Return in Indonesia

\begin{tabular}{llccc}
\hline & Variable & Mean & df & Sig. (2-tailed) \\
\hline Pair 1 & $\begin{array}{c}\text { AAR Before-After } \\
\text { Indonesia }\end{array}$ & -.00995 & 6 & 0.420 \\
\hline
\end{tabular}

Table 8 shows the results of AAR in Indonesia before and after the initial announcement of the policy with a value of 0,420 . This result means that H1a is rejected because the value of Sig.(2-tailed) is greater than 0,05 . Thus, the initial announcement of the Covid-19 pandemic lockdown policy in Indonesia did not show a significant difference before and after the announcement of the lockdown policy.

Table 9 Results of Paired Sample t-test Average Abnormal Return in Singapore

\begin{tabular}{llccc}
\hline & Variable & Mean & df & Sig. (2-tailed) \\
\hline Pair 1 & AAR Before-After & -.00192 & 6 & 0.587 \\
& Singapore & & & \\
\hline
\end{tabular}

Table 9 shows the result of AAR test before and after the announcement of the lockdown policy in Singapore, showing a value of 0,587 . This result means that $\mathrm{H} 1 \mathrm{~b}$ is rejected because the value of sig (2-tailed) is greater than 0,05 . Thus, it did not show a significant difference before and after the announcement of the lockdown policy in Singapore.

Table 10 Results of Paired Sample t-test Average Abnormal Return in Malaysia

\begin{tabular}{llccc}
\hline & Variable & Mean & df & Sig. (2-tailed) \\
\hline Pair 1 & $\begin{array}{l}\text { AAR Before-After } \\
\text { Malaysia }\end{array}$ & .00208 & 6 & 0.524 \\
\hline
\end{tabular}

Table 10 shows the result of AAR test before and after the announcement of the lockdown policy in Malaysia, showing that there is not significant difference from before to after the announcement was made. This is shown by the value of sig (2-tailed) which is greater than 0,05 , meaning that $\mathrm{H} 1 \mathrm{c}$ is rejected. 
Lailatul Fauziah, Lintang Venusita / The Reaction of Capital Markets in Indonesia, Singapore, Malaysia, and Thailand towards the Announcement of Lockdown Policy During the Beginning of the Covid-19

Table 11 Results of Paired Sample t-test Average Abnormal Return in Thailand

\begin{tabular}{llccc}
\hline & Variable & Mean & df & Sig. (2-tailed) \\
\hline Pair 1 & AAR Before-After & -.00221 & 6 & 0.741 \\
& Thailand & & & \\
\hline
\end{tabular}

Table 11 shows the result of AAR test before and after the announcement of the lockdown policy in Thailand, showing that there is not significant different since before and after the even period. This is shown by the value of sig (2-tailed) which is greater than 0,05 , meaning that $\mathrm{H} 1 \mathrm{~d}$ is rejected.

\section{Hypothesis 2 Test}

In the third testing, $2^{\text {nd }}$ hypothesis testing is conducted to see if there is any difference of reaction from before to after the announcement of the Covid-19 pandemic lockdown policy, indicated by the average trading volume activity of each country. Based on the result of the normality testing, hypothesis 2 test for Indonesia and Thailand are conducted via Wilcoxon Signed Rank Test as the ATVA data of both countries are not normally distributed. While Singapore and Malaysia will be tested via paired sample t-test as the ATVA data of both countries are normally distributed.

Table 12 Results of Wilcoxon Signed Rank Test Average Trading Volume Activity Indonesia

\begin{tabular}{cc}
\hline & ATVA before-after Indonesia \\
\hline Z & -.507 \\
Asymp Sig. (2-tailed) & 0.612 \\
\hline
\end{tabular}

According to Tale 12, the result of average trading volume activity in Indonesia shows that there is no significant different from before to after the

Table 13 Results of Wilcoxon Signed Rank Test Average Trading Volume Activity in Thailand

\begin{tabular}{cc}
\hline & ATVA before-after Thailand \\
\cline { 2 - 2 } Z & -1.014 \\
Asymp Sig. (2-tailed) & 0.310 \\
\hline
\end{tabular}


announcement of lockdown policy in Indonesia. This is shows with the value of Asymp sig. (2-tailed) as greater than 0,05 , thus H1b is rejected.

Table 13 shows the results of ATVA from companies in Thailand, which shows that the value of Asymp. Sig (2-tailed) is greater than 0,05 thus hypothesis 2 , specifically $\mathrm{H} 2 \mathrm{~d}$ is rejected. This indicates that the announcement of lockdown during the start of Covid-19 pandemic in Thailand did not bring significant effect towards the capital market.

Table 14 Results of Paired Sample t-test Average Trading Volume Activity in Singapore

\begin{tabular}{llccc}
\hline & Variable & Mean & df & Sig. (2-tailed) \\
\hline Pair 1 & $\begin{array}{l}\text { ATVA Before-After } \\
\text { Singapore }\end{array}$ & 4000481 & 6 & 0.05 \\
\hline
\end{tabular}

According to Table 14, the ATVA from companies in Singapore are tested with Paired Sample t-test, and it is found that the value of sig (2-tailed) is equal to 0,05 , thus the second hypothesis of $\mathrm{H} 2 \mathrm{~b}$ is accepted. This shows that there is a significant difference before and after the announcement of lockdown during the start of Covid-19 in Singapore.

Table 15 Results of Paired Sample t-test Average Trading Volume Activity in Malaysia

\begin{tabular}{llccc}
\hline & Variable & Mean & df & Sig. (2-tailed) \\
\hline Pair 1 & $\begin{array}{l}\text { ATVA Before-After } \\
\text { Malaysia }\end{array}$ & 356056 & 6 & 0.883 \\
\hline
\end{tabular}

According to Table 15, the ATVA from Malaysian capital market shows that the value of sig (2-tailed) is greater than 0,05 , which is 0,883 . Thus, the second hypothesis of $\mathrm{H} 2 \mathrm{c}$ is rejected. This shows that the announcement of policy in Malaysia does not bring significant effect before and after the announcement of lockdown policy.

\section{DISCUSSION}

Capital market reaction is an event that can be indicated by the presence of abnormal return generated from the issuer in the capital market within the 
observation period. The reaction test is observed during the initial announcement of lockdown policy during the beginning of the Covid-19 pandemic in Indonesia, Singapore, Malaysia, and Thailand. During the period of capital market observation to the four ASEAN countries, Indonesian capital market shows a significant reaction in several days. The reactions occurred during the day when the government announce the policy and is going on for the next 2 days after the announcement were made. In addition, the reactions were also found in 3 consecutive days before the government announce the policy. The positive reactions are in line with NOO Noor et al. (2020) study, which shows that there is a positive AAR during the lockdown policy phase in India. This reaction may happen as the public, especially investors, hoped that the government's policies can stop the spread of the virus. Indonesian capital market reactions to the information about the announcement quickly shows that Indonesian capital market has a semi-strong form of market efficiency because the market reflects on the incoming information with prolonged abnormal returns of 3 days. This finding also strengthens the results of a study on Indonesian capital market form conducted by Rante et al. (2019), who stated the Indonesian capital market leans towards a semi-strong form of efficiency.

Singapore and Thailand capital market also responded to the information on policy announcement during the observation period but was not prolonged. The reaction only found on a few days; thus, the efficiency of both countries can be said as heading towards a semi-strong form of market efficiency. Differently, Malaysian capital market did not show any significant reaction on the abnormal return during the observation period. The absence of reaction was possible because during the observation period, the government has implemented policies starting on March 18, 2020. Thus, the investors were more focused once the policy was implemented. According to this finding, Malaysian capital market has not been efficient in receiving new information. Thus, the non-prolonged average market reaction in the four countries shows that not only the information regarding the lockdown policy is the basis for decision making from the investors, but the existence of other policies issued by the government can influence investors' investing decisions during the pandemic period.

According to the results of testing on the average abnormal return of the capital market before and after the event, the results show that the $\mathrm{H} 2 \mathrm{a}, \mathrm{H} 2 \mathrm{~b}$, 
$\mathrm{H} 2 \mathrm{c}$, and $\mathrm{H} 2 \mathrm{~d}$ hypotheses are rejected. This indicated that the existence of the policy does not have significant effect towards the capital market, including the investors. The research findings are different from a research conducted by Noor et al. (2020) regarding the lockdown policy in India, which shows a positive effect after the policy was implemented.

The absence of capital market reaction in Indonesia, Singapore, Malaysia, and Thailand before and after the policy means that the information at the time of the announcement of the lockdown policy in each country did not have important or meaningful information to the capital market. In addition, the absence of market reaction is also thought to be caused by investors no believing in how the lockdown policy can improve the capital market conditions. IN addition, the existence of other external factors raised by the government can also be the basis of decision making besides the lockdown policy.

Apart from abnormal return, capital market reactions can also be shown from the movement of trading volume activity of the market. Based on the results of testing of the capital market activity, the announcement of the lockdown policy in the beginning of Covid-19 pandemic in Indonesia, Malaysian, and Thailand did not show a significant difference between the period of before and after the announcement. This means that the governments' announcement on the lockdown policy is not used by the investors as a reason or basis for making decision to buy or sell shares in the capital market during the observation period. The insignificant effect occurred due to investors' consideration in making decision, especially during the pandemic period where the conditions of the world's capital market were unstable. In contrast with the reactions of capital market in Indonesia, Malaysia, and Thailand, Singaporean's capital market shows a significant reaction in the movement of trading volume or trading volume activity (TVA) before and after the lockdown policy in Singapore. This indicates that Singapore's capital market absorbed important information from the announcement of the Covid-19 lockdown policy by the government. In addition, the different reactions show that investors use information about the policy as a basis to decide whether to buy or sell, thus the trading activities occurred. This is in line with a study by Wibowo \& Sukmaningrum (2020) which shows a different reaction on the capital market before and after the existence of a government's policy. The existence of market reactions show that the content of 
published information has a value for investors to make different decisions compare to investing in normal conditions.

\section{Conclusion}

According to the data testing and the discussions conducted, the study can be concluded as follow:

1. Capital market's reaction shown by the abnormal return during the observation period shows that the capital market and the investors accept the incoming information as a basis for making investment decision. However, information on lockdown policy is not the only one factor that affect the decision making, but also other external information issued by the government.

2. The effect of announcement of lockdown policy during the beginning of Covid-19 pandemic towards abnormal return does not show a significant effect before and after the announcement was made in Indonesia, Singapore, Malaysia, and Thailand. This shows that the announcement on lockdown policy by the government on a pandemic period does not have a valuable information to the capital market in each country, namely LQ45, STI, FBM KCLI and SET50.

3. The effect of announcement of lockdown policy during the beginning of Covid-19 pandemic towards trading volume activity does not have a significant effect on Indonesian, Malaysian, and Thailand capital market before and after the policy announcement. The absence of reactions in the three countries' capital market indicates that the investors have not fully use the information on the policy to be able to conduct trading activities on the capital market.

4. The ASEAN capital market shows different forms of market efficiency due to the different reactions of the capital market in each country. Indonesian capital market shows a moderate form of market efficiency. This is due to how the capital market shows prolonged reactions during the observation period. Singapore and Thailand capital market also show that both capital markets are heading towards moderate strength because the capital market shows a reaction, even though it is not in prolonged period. While Malaysian capital market does not show any reaction during the observation period. 


\section{Suggestion}

Below are some suggestions given from this study, including:

1. For future researchers

Suggestions for future researcher are to observe or extend the observation window because there is possibility where information about the policy that have not been understood by the capital market. In addition, researchers can also conduct studies with different research objects so we can get detailed reactions from the new information in the capital market.

2. For investors

Suggestions for investors are to absorb or to deepen the connection of information announced by the government during this pandemic. This is caused by the capital market is in unstable state due to uncertain economic conditions due to the pandemic. Thus, by absorbing the right information, investors can receive return by minimizing the uncertain risks from the capital market.

\section{REFERENCES}

Anh, D. L. T. \& Gan, C. (2020). The Impact of the Covid-19 Lockdown on Stock Market Performance: Evidence from Vietnam. Journal of Economic Studies. https://doi.org/10.1108/JES-06-2020-0312.

Baig, A. S., Butt, H. A., Haroon, O., \& Rizvi, S. A. R. (2020). Deaths, Panic, Lockdowns and US Equity Markets: The Case of Covid-19 Pandemic. Finance Research Letters, July, 101701. https://doi.org/10.1016/j.frl.2020. 101701.

Ferguson, A. \& Lam, P. (2016). Government Policy Uncertainty and Stock Prices: The Case Of Australia's Uranium Industry. Energy Economics, 60, 97-111. https://doi.org/10.1016/j.eneco.2016.08.026.

Hartono, J. (2017). Teori Portofolio dan Analisis Investasi (Ed 11).

Haryanto. (2020). Dampak Covid-19 terhadap Pergerakan Nilai Tukar Rupiah dan Indeks Harga Saham Gabungan (IHSG). Jurnal Perencanaan Pembangunan: The Indonesian Journal of Development Planning, 4(2), 151-165. https://doi.org/10.36574/jpp.v4i2.114. 
Huo, X. \& Qiu, Z. (2020). How does China's stock market react to the announcement of the Covid-19 pandemic lockdown? Economic and Political Studies, 0(0), 1-26. https://doi.org/10.1080/20954816.2020.1780695.

Narayan, P. K., Phan, D. H. B., \& Liu, G. (2020). Covid-19 Lockdowns, Stimulus Packages, Travel bans, and Stock Returns. Finance Research Letters, July, 101732. https://doi.org/10.1016/j.frl.2020.101732.

Noor, M., Shabbir, M., \& Kavita. (2020). Stock Market Response during Covid19 Lockdown Period in India: An Event Study. Journal of Asian Finance, Economics and Business, 7(7), 131-137. https://doi.org/10.13106/jafeb.2020. vol7.no7.131.

OECD. (2020). Coronavirus: The world economy at risk. OECD Interim Economic Assessment, March, 1-15. http://www.oecd.org/berlin/publikationen/Interim-Economic-Assessment-2-March-2020.pdf.

Rante, T., Falah, S., \& Pangayow, B. J. . (2019). Reaksi Pasar Modal terhadap Pengumuman Paket Kebijakan Ekonomi XVI (Studi Empiris pada Saham Perusahaan yang Masuk dalam Indeks LQ 45). Jurnal Akuntansi \& Keuangan Daerah, 14(November), 112-123.

Saragih, H. P. (2020). WHO Tetapkan Corona Pandemi Dunia, IHSG Sempat Anjlok 4,3\%. CNBC. https://www.cnbcindonesia.com/market/20200312103117-17-144278/who-tetapkan-corona-pandemi-dunia-ihsg-sempatanjlok-43.

Shen, C. H., Bui, D. G., \& Lin, C. Y. (2017). Do political factors affect stock returns during presidential elections? Journal of International Money and Finance, 77, 180-198. https://doi.org/10.1016/j.jimonfin.2017.07.019.

Spinelli, A., \& Pellino, G. (2020). Covid 19 Pandemic: Perspectives on an Unfolding Crisis. National Center for Biotechnology Information, US National Library of Medicine. https://www.ncbi.nlm.nih.gov/pmc/articles/ PMC7228411/\#bjs11627-bib-0001.

Wardhani, L. S. (2012). Reaksi Pasar Modal Indonesia Terhadap Peristiwa Pemilihan Gubernur DKI Jakarta Putaran II 2012 (Event Study pada Saham Anggota Indeks Kompas 100). Jurnal Ilmiah Mahasiswa FEB, 1(1), 129-142.

Wibowo, M. S., \& Sukmaningrum, P. S. (2020). Stock Market Reaction to the Tax Amnesty Announcement. Indonesian Capital Market Review, 11(2), 108-118. https://doi.org/10.21002/icmr.v11i2.11608. 
Journal of Accounting, Entrepreneurship, and Financial Technology

Volume 02, Number 02, April 2021 